AL-MASHRAFIYAH: Jurnal Ekonomi, Keuangan, dan Perbankan Syariah

ISSN (p): 2597-4904 ISSN (e) : 2620-5661

Volume 3, Nomor 2, Oktober (2019), h. 95-107

https://doi.org/10.24252/al-mashrafiyah.v3i2.9273

\title{
KOMPARASI EFISIENSI PENYALURAN KREDIT PADA BANK UMUM SYARIAH (BUS) ANTARA BANK MEGA SYARIAH DAN BANK CIMB NIAGA SYARIAH DENGAN PENDEKATAN DATA ENVELOPMENT ANALYSIS (DEA)
}

\author{
Murtiadi Awaluddin $^{1}$, Aenun Mutmainna ${ }^{2}$, Rulyanti Susi Wardhani ${ }^{3}$ \\ ${ }^{1}$ Program pascasarjana UIN Alauddin Makassar \\ ${ }^{2}$,Fakultas Ekonomi dan Bisnis Islam UIN Alauddin Makassar \\ ${ }^{3}$ Fakultas Ekonomi, Universitas Bangka Belitung, Kampus Terpadu UBB. \\ murtiadi.awaluddin@uin-alauddin.ac.id ${ }^{1}$, ainunmutmainna@gmail.com², \\ rulyantiwardhani67@gmail.com ${ }^{3}$
}

\begin{tabular}{l}
\hline Keywords: \\
Efficiency, Data \\
Envelopment \\
Analysis, Total \\
Deposits, Sharia \\
Commercial \\
Banks
\end{tabular}

Kata Kunci:

Efisiensi, Data

Envelopment

Analysis, Total

Aset, Bank

Umum Syariah

\section{ABSTRACT}

Efficiency is one of the performance parameters that underlies the entire performance of an organization by proposing to the philosophy of the ability to produce optimal output with existing inputs. In this Article using the ratio approach with the purpose to measure the efficiency and comparison of efficiency between Bank. Mega Syariah and CIMB Niaga Syariah Bank during the period 2010-2016. The data used in this study are secondary data collected from financial reports issued by Bank Indonesia. Efficiency measurement in this study uses the Data Envelopment Analysis (DEA) method. The input used is total savings, total assets, and labor costs, while the output variable is total financing or credit and operating profit. To find out the comparison of efficiency between Bank. Mega Syariah and CIMB Niaga Syariah Bank, this study used Independent Sample T-Test different tests. The results of this study indicate that there is a significant comparison between Bank. Mega Syariah and CIMB Niaga Syariah Bank. In this study CIMB Niaga Syariah Bank showed a better level of efficiency than Bank Mega Syariah

\section{ABSTRAK}

Efisiensi merupakan salah satu parameter kinerja yang mendasari seluruh kinerja sebuah organisasi dengan mengaju pada filosofi kemampuan menghasilkan output yang optimal dengan input yang ada. Dalam artikel ini menggunakan pendekatan rasio dengan tujuan untuk mengukur efisiensi dan perbandingan efisiensi antara Bank Mega Syariah dan Bank CIMB Niaga Syariah selama periode 2010-2016. Data yang digunakan dalam penelitian ini adalah data sekunder yang dikumpulkan dari laporan keuangan yang diterbitkan oleh Bank Indonesia. Pengukuran efisiensi dalam penelitian ini menggunkan metode Data Envelopment Analysis (DEA). Input yang digunakan adalah total simpanan, total aset, dan biaya tenaga kerja, sedangkan variable outputnya adalah total pembiayaan atau kredit dan laba opersional. Untuk mengetahui perbandingan efisiensi antara Bank Mega Syariah dan Bank CIMB Niaga Syariah, penelitian ini menggunakan uji beda Independent Sample T-Test. Hasil penelitian ini menunjukan bahwa terdapat perbandingan yang siginfikan antara Bank Mega syariah dan Bank CIMB Niaga Syariah. Pada penelitian ini Bank CIMB Niaga Syariah menunjukan tingkat efisiensi yang lebih baik daripada Bank Mega Syariah. 
Murtiadi Awaluddin, et al. Komparasi Efisiensi Penyaluran Kredit...

\section{PENDAHULUAN}

Perkembangan dunia perbankan sejak dilanda krisis moneter tahun 1997 sangat tidak menggembirakan sampai tahun 2001. Dan diperkirakan untuk pulih kembali seperti sediakala memerlukan waktu paling sedikit 10 tahun mendatang. Ambruknya bisnis perbankan akibat kesalahan kebijakan pemerintah maupun kesalahan manajemen perbankan sendiri tidak hanya merugikan dunia perbankan semata. Dampak yang lebih besar adalah mandeknya kehidupan di sektor rill akibat kekurangan suplai dana dari dunia perbankan. Sementara itu Perkembangan dunia keuangan khususnya perbankan diera tahun 2000-an telah memasuki masa kebangkitan dari keterpurukan setelah dierah krisis ekonomi tahun 1997 yang lalu. Kemajuan ini ditunjukkan dunia perbankan melalui jumlah dana yang mampu diserap dari masyarakat dan disalurkan kembali ke masyarakat terus meningkat dengan diiringi kualitas yang baik pula. Disamping mengalami peningkatan jumlah dana, dunia keuangan juga terus tumbuh dalam jumlah nasabah, hal ini tentunya tidak lepas dari layanan yang diberikan sangat memanjakan nasabahnya serta makin beragamnya produk yang ditawarkan (Kasmir, 2012).

Keberadaan sektor perbankan sebagai sub-sistem dalam perekonomian suatu negara memiliki peranan yang cukup penting. Bahkan dalam kehidupan suatu masyarakat modern sehari-hari. Sebagian besar hampir melibatkan jasa-jasa dari sektor perbankan (Bachruddin,2006). Melalui bank-bank dapat dihimpun dana-dana dari masyarakat dalam berbagai bentuk simpanan. Selanjutnya dari dana yang terkumpul tersebut oleh bank-bank dapat disalurkan kembali dalam bentuk pemberian kredit kepada sektor bisnis atau pihak-pihak lainnya. Semakin berkembang kehidupan masyarakat dan transaksi-transaksi perekonomian suatu Negara, akan membutuhkan pula peningkatan peran disektor perbankan melalui pengembangan produk-produk jasanya (Bacharuddin, 2006).

Perbankan merupakan tonggak utama dalam pengukuran pertumbuhan ekonomi negara. Di Indonesia, perbankan digolonkan menjadi dua, yakni bank syariah dan bank konvensional. Namun seiring dengan perkembangan perbankan Indonesia, kini muncul dual banking system, yaitu perbankan konvensional yang memiliki unit usaha syariah. Munculnya perbankan syariah diharapkan mampu mendorong dan mempercepat kemajuan ekonomi suatu masyarakat dalam melakukan kegiatan perbankan, sesuai dengan prinsip syariah islam. Dalam beberapa tahun terakhir, lembaga keuangan telah mengalami perkembangan yang cukup dinamis, cepat dan kompetitif. Salah satu bagian yang sedang berkembang adalah paradigma baru perbankan islam (Uctavia, 2013).

Perkembangan perbankan islam merupakan fenomena yang menarik bagi kalangan akademisi ataupun praktisi dalam 20 tahun terakhir. Bahkan IMF telah melakukan kajian-kajian atas praktik perbankan islam sebagai alternative system keuangan internasional yang memberikan peluang upaya penyempurnaan sistem keuangan internasional yang belakangan dirasakan banyak sekali mengalami keterpurukan ekonomi akibat lebih dominalnya sektor finansial dibandingkan dengan sektor real dalam hubungan perekonomian dunia (Umam,Khaerul, 2013). Sejarah perbankan syariah di Indonesia dimulai dengan berdirinya Bank Muamala Indonesia (BMI) pada tahun 1991 yang diprakarsai oleh Majelis Ulama Indonesia (MUI) dan pemerintah Indonesia. Bank Muamala Indonesia mulai beroperasi setelah berlakunya Undang-Undang No. 1 Tahun 1992 tentang perbankan syariah yang membuka kesempatan bagi bank yang melaksanakan profit bagi hasil ini (Setiawan, 2013).

Penilaian efisiensi bank menjadi sangat penting dengan kondisi seperti ini, karena efisiensi merupakan gambaran kinerja suatu bank sekaligus menjadi faktor yang harus diperhatikan bank untuk bertindak rasional dalam meminimumkan tingkat risiko yang dihadapi dalam menghadapi kegiatan operasinya. Analisis mengenai efisiensi menjadi sangat penting karena penghimpunan dan peyaluran pembiayaan yang ekspansif tanpa memperhatikan faktor efisiensi akan berpengaruh terhadap profitabilitas bank yang bersangkutan (Muharam dan Pusvitasari, 2007). Apalagi jika tidak hanya satu bank saja yang dianalisis efisiensinya, akan tetapi juga diperbandingkan dengan nilai efisiensi bank-bank lain. Hasil perbandingan ini 
sangat berguna dan bisa dijadikan acuan untuk pihak- pihak terkait. Bagi pemilik bank, bisa memperbaiki kinerja banknya dengan mencontoh kinerja bank lain yang mencapai tingkat efisiensi lebih baik, sedangkan bagi masyarakat, sebagai pengguna jasa bank bisa mendapatkan pandangan untuk memilih bank mana yang akan dituju. Astiyah dan Husman (2006) menjelaskan bahwa efisiensi bank bukan hanya sebagai indikator penting dalam perbankan, tetapi juga sarana penting untuk lebih meningkatkan efektivitas kebijakan moneter. Perbankan yang efisien diperkirakan dapat memperlancar proses transmisi kebijakan moneter, sehingga kebijakan moneter dapat lebih efektif mencapai sasaran.

Efisiensi merupakan perbandingan antara output dengan input (Huri dan Susilowati,2004). Kemampuan menghasilkan output yang maksimal dengan imput yang ada merupakan ukuran kinerja yang diharapkan. Pada saat pengukuran efisiensi dilakukan, lembaga keuangan dihadapkan pada kondisi bagaimana mendapatkan tingkat output yang optimal dengan input yang ada atau dengan cara mendapatkan tingkat input yang minimum dengan tingkat output tertentu (Coeli dan Guide, 1996). Efisiensi perbankan selain diukur dengan melihat perbandingan indikator kinerja perbankan dan rasio keuangan, ada juga beberapa metode lain, yaitu pendekatan parametrik dan non parametrik. Pendekatan parametrik meliputi Stochastic Frontier Approach (SFA), Distribution Free Approach (DFA) dan Thick Frontier Approach (TFA), sedangkan non parametrik dengan pendekatan Data Envelopment Analysis (DEA) (Coeli dan Guide, 1996).

Menurut Hadad (2003), analisis evaluasi efisiensi pebankan tepat bila menggunakan evaluasi parametrik atau non parametrik. Hal ini dikarenakan kemampuan kedua metode tersebut yang dapat memasukkan berbagai macam input dan output ke dalam analisisnya. Selain itu perbedaan satuan variabel pun tidak menjadi masalah, dimana hal tersebut sebelumnya tidak dapat dilakukan oleh alat analisis yang lain sehingga alat analisis efisiensi parametrik dan non parametrik sifatnya lebih fleksibel dan dapat mencakup variabel yang lebih luas dibandingkan dengan alat analisis yang lain.

Pengukuran efisiensi BUS dalam penelitian ini akan menggunakan metode Data Envelopment Analysis (DEA). Metode ini memiliki kelebihan yaitu tidak membutuhkan asumsi bentuk fungsi produksi dalam membentuk frontier produksinya, oleh karena itu kesalahan dalam spesifikasi fungsi produksi dapat dieliminasi (Ascarya dan Guruh, 2008). Epstein dan Henderson (1989) dalam Hadad, Muliaman D., dkk. (2003) juga menambahkan pendapatnya tentang keuntungan relatif penggunaan pendekatan ini lebih besar dibandingkan parametrik, yaitu pendekatan ini dapat mengidentifikasi unit yang digunakan sebagai referensi sehingga dapat membantu mencari penyebab dan jalan keluar dari ketidakefisienan yang merupakan keuntungan utama dalam aplikasi manajerial. Karakteristik pengukuran efisiensi dengan metode DEA memiliki konsep yang berbeda dengan efisiensi pada umumnya, pertama, efisiensi yang diukur adalah bersifat teknis, bukan ekonomis, artinya bahwa analisis DEA hanya memperhitungkan nilai absolut dari satu variabel. Satuan dasar yang mencerminkan nilai ekonomis dari tiap-tiap variabel seperti harga, berat, panjang, isi dan lainnya tidak dipertimbangkan. Oleh karenanya dimungkinkan suatu pola perhitungan kombinasi berbagai variabel dengan satuan yang berbeda-beda. Kedua, nilai efisien yang dihasilkan bersifat relatif atau hanya berlaku dalam lingkup sekumpulan Unit Kegiatan Ekonomi (UKE) yang diperbandingkan (Nugroho, 1995 dalam Huri dan Susilowati, 2004).

\section{LANDASAN TEORI}

\section{Teori Efisiensi}

Efisiensi adalah kemampuan untuk menyelesaikan suatu pekerjaan dengan benar atau dalam pendangan matematika didefinisikan sebagai perhitungan rasio output (keluaran dan 
input (masuk) atau jumlah keluaran yang dihasilkan dari suatu input yang digunakan. Dalam kamus besar bahasa Indonesia, efisiensi diterjemahkan dengan daya guna. Ini menunjukan bahwa efisiensi selain menekankan pada hasilnya, juga ditekankan pada daya atau usaha/pengorbanan untuk mencapai hasil tersebut agar tidak terjadi pemberosan.

Sedangkan menurut Ghiselli dan Brown (2004) mengemukalam "The term efficiency has a very exact definition, it is expessed as the ratio of output to input". Jadi, menurut Ghiselli dan Brown istilah efiiensi mempunyai pengertian yang sudah pasti, yaitu menunjukan adanya perbandingan antara output da input. Menurut Zainal Abidin dan Endri (2009) bahwa efisiensi perusahaan terdiri dari dua komponen yaitu.

1. Efisiensi teknis, efisiensi ini mencerminkan kemampuan untuk memproduksi output semaksimal mungkin dan input yang ada. Efisiensi secara teknis bukan berarti efisien dalam hal efisiensi harga atau alokatif.

2. Efisiensi alokatif, efisiensi alokatif menggambarkan kemampuan perusahaan untuk menggunkan input dalam proporsi yang optimal yang juga memasukan perhitungan biaya. Perusahaan dianggap efisien alokatif jika perusahaan menghasilkan output dengan biaya seminimal mungkin dengan menggunakan minimal input.

Dari beberapa pengertian efisiensi diatas, dapat disimpulkan bahwa efisiensi adalah kegiatan mencapai tujuan dengan benar, dengan cara menggunakan input yang minimal secara optimal dengan hasil output yang maksimal.

\section{Pengukuran Efisiensi}

Menurut Muharam dan Pusvitasari (2007), ada tiga jenis pendekatan pengukuran efisiensi khususnya perbankan, salah satunya adalah pendekatan rasio.

1. Pendekatan Rasio

Pendekatan rasio dalam mengukur efisiensi dilakukan dengan cara menghitung perbandingan output dan input yang digunakan. Pendekatan ini akan dapat dinilai memiliki efisiensi yang tinggi apabila dapat menghasilkan output yang semaksimal mungkin dengan input yang seminimal mungkin.

$$
\text { Effesiency }=\frac{\text { Output }}{\text { Input }}
$$

Pendekatan rasio ini mempunyai kelemahan apabila terdapat banyak input dan banyak output yang dihitung, jika diperhitungkan serempak maka akan menghasilkan banyak hasil perhitungan sehingga menghasilkan asumsi yang tidak tegas (Silkman dalam Muharam dan Purvitasari, 2007).

2. Pedekatan Regresi

Pendekatan ini dalam mengukur efisiensi menggunakan sebuah model dari tingkat output tertentu sebagai fungsi dari berbagai tingkat input tertentu. Fungsi regresi adalah sebagai berikut:

$$
\begin{aligned}
& Y=f\left(X_{1}, X_{2}, X_{3}, X_{4}, \ldots \ldots \ldots . . . . X_{n}\right) \\
& \text { Dimana: } \\
& \mathrm{Y}=\text { Output } \\
& \mathrm{X}=\text { Input }
\end{aligned}
$$

Pendekatan regresi akan menghasilkan estimasi hubungan yang dapat digunakan untuk memproduksi tingkat output yang dihasilkan sebuah Unit Kegiatan Ekonomi (UKE) pada tingkat input tertentu. UKE dapat dikatakan efisien apabila menghasilkan output lebih banyak dari pada output hasil estimasi. Kelemahan dalam pendekatan ini adalah ketidakmampuannya dalam menampung banyak output, karena dalam sebuah persamaan regresi hanya dapat menampung satu indikator output. Apabila dilakukan penggabungan banyak output dalam satu indikator maka informasi yang dihasilkan menjadi tidak rinci lagi (Silkman, 1986 dalam Muharam dan Purvitasari, 2007). 


\section{Pendekatan Frontier}

Menurut Silkman (1986) dalam Muharam dan Purvitasari (2007), pendekatan frontier dalam mengukur efisiensi dibedakan menjadi dua jenis yaitu pendekatan frontier parametrik dan non parametrik. Tes parametrik adalah tes yang modelnya menetapkan adanya syaratsyarat tertentu tentang parameter populasi yang merupakan sumber penelitiannya, sedangkan tes statistik non parametrik adalah tes yang modelnya tidak menetapkan syarat-syarat mengenai parameter populasi yang merupakan induk sampel penelitiannya. Pendekatan frontier parametrik dapat diukur dengan tes statistik parametrik seperti menggunakan metode Stochastic Frontier Analysis (SFA) dan Distribution Free Analysis (DFA). Sedangkan pendekatan frontier non parametrik dapat diukur dengan tes statistik non parametrik dengan menggunakan metode Data Envelopment Analysis (DEA).

\section{Efisiensi Perbankan}

Efisiensi dalam perbankan, seperti halnya persahaan juga merupakan tolak ukur dalam mengukur kinerja bank. Dimana efisiensi merupakan jawaban atas kesulitan-kesulitan dalam menghitung ukuran-ukuran kinerja seperti tingkat alokasi, teknis, maupun total efisiensi (Hadad, 2003). Efisiensi perbankan didefinisikan sebagai perbedaan antara jumlah variable input dan output yang diamati dengan variable input dan output yang optimal. Bank yang efisien dapat mencapai nilai maksimal satu dan bank infisien nilainya belum maksimal (Haseeb, 2010).

Efisiensi industry perbankan dapat ditinjau dari satu sudut pandang mikro maupun makro (Berger dan Master,1997). Dari perspektif mikro, dalam suasana persaingan yang semakin ketat sebuah bank agar bisa bertahan dan berkembang harus efisien dalam kegiatan opersionalnya. Bank-bank yang tidak efisien, besar kemungkinan akan exit dari pasar karena tidak mampu bersaing dengan kompetitornya, baik dari segi harga (pricing) maupun dalam hal kualitas produk dan pelayanan. Bank yang tidak efisien juga akan kesulitan dalam mempertahankan kestiaan nasabahnya dan juga tidak diminati oleh calon nasabah dalam rangka untuk memperbesar cutomer-basenya.

\section{Konsep Data Envelopment Analysis (DEA)}

DEA dikembangkan pertama kali oleh Farrel (1957) yang mengukur efisiensi teknik satu input dan satu output menjadi multi input dan multi output, menggunakan kerangka nilai efisiensi relatif sebagai rasio input dengan output (Giuffrida dan Gravelle, 2001). Alat analisis ini dipopulerkan oleh beberapa peneliti lainnya, di antaranya (Sutawijaya dan Lestari, 2009):

1. Charnes-Cooper-Rhodes (1978)

Para peneliti ini pertama kali menemukan model DEA CCR (Charnes- CooperRhodes) pada tahun 1978. Menurut Muharam dan Pusvitasari (2007), model ini mengasumsikan adanya Constant Return to Scale (CRS). CRS adalah perubahan proporsional yang sama pada tingkat input akan menghasilkan perubahan proporsional yang sama pada tingkat output (misalnya: penambahan 1 persen input akan menghasilkan penambahan 1 persen output).

2. Bankers, Charnes dan Cooper (1984)

Beberapa peneliti ini mengembangkan lebih lanjut model DEA BCC (Bankers, Charnes dan Cooper) pada tahun 1984. Muharam dan Pusvitasari (2007) menyebutkan bahwa model ini mengasumsikan adanya Variable Return to Scale (VRS). VRS adalah semua unit yang diukur akan menghasilkan perubahan pada berbagai tingkat output dan adanya anggapan bahwa skala produksi dapat mempengaruhi efisiensi. Hal inilah yang membedakan dengan asumsi CRS yang menyatakan bahwa skala produksi tidak mempengaruhi efisiensi. Teknologi merupakan salah satu faktor yang mempengaruhi VRS, sehingga membuka kemungkinan skala produksi mempengaruhi efisiensi. 
Murtiadi Awaluddin, et al. Komparasi Efisiensi Penyaluran Kredit...

Menurut Kurnia (2004), DEA termasuk salah satu alat analisis non parametrik yang digunakan untuk mengukur efisiensi secara relatif baik antar organisasi bisnis yang berorientasi laba (profit oriented) maupun antar organisasi atau pelaku kegiatan ekonomi yang tidak berorientasi laba (non-profit oriented) yang dalam proses produksi atau aktivitasnya melibatkan penggunaan input tertentu untuk menghasilkan output tertentu.

Alat analisis ini juga dapat mengukur efisiensi basis dan alat pengambil kebijakan dalam peningkatan efisiensi. Sutawijaya dan Lestari (2009) menambahkan bahwa DEA dapat digunakan di berbagai bidang, antara lain: kesehatan (health care), pendidikan (education), transportasi (transportation), pabrik (manufacturing), maupun perbankan.

Adapun kelemahan dan kelebihan DEA, di antaranya (Purwantoro 2003 dalam Huri dan Susilowati 2004):

a. Keunggulan DEA, meliputi:

1. Dapat menangani banyak input dan output.

2. Tidak perlu asumsi hubungan fungsional antara variabel input dan output.

3. UKE dibandingkan secara langsung dengan sesamanya.

4. Input dan output dapat memiliki satuan pengukuran yang berbeda.

b. Kelemahan DEA, yaitu:

1. Bersifat sample specific (DEA berasumsi bahwa setiap input atau output identik dengan unit lain dalam tipe yang sama).

2. Merupakan extreme point technique.

3. Kesalahan pengukuran dapat berakibat fatal.

4. Hanya untuk mengukur produktivitas relatif dari UKE bukan produktivitas absolut.

5. Uji hipotesis secara statistik atas hasil DEA sulit dilakukan.

\section{Bank Umum Syariah (BUS)}

Bank umum syariah merupakan salah satu bentuk dari perbankan nasional yang mendasarkan operasionalnya pada syariat (Hukum) islam. Menurut Schaik (2001), bank islam adalah sebuah bentuk dari bank modern yang didasarkan pada hukum islam yang sah, dikembangkan pada abad pertama islam, menggunakan konsep berbagai risiko sebagai metode utama, dan meniadakan keuangan berdasarkan kepastian serta keuntungan yang ditentukan sebelumnya (Khaerul Umam,2013). Bank syariah adalah bank yang menjalankan kegiatan usahanya berdasarkan prinsip syariah dan menurut jenisnya terdiri atas Bank Umum Syariah dan Bank Pembiayaan Rakyat Syariah. Prinsip syariah adalah prinsip hokum islam dalam kegiatan perbankan berdasarkan fatwa yang dikeluarkan oleh lembaga yang memilki kewanangan dalam penentapan fatwa di bidang syariah (Booklet Perbankan Indonesia, 2016).

\section{Kinerja Perbankan}

Untuk menjamin suatu organisasi berjalan dengan baik, maka suatu organisasi atau perusahaan perlu mengadakan evaluasi. Evaluasi tersebut dapat dilakukan dengan cara mengukur kinerjanya, sehingga aktivitas organisasi dapat dipantau secara periodic. Pengukuran kinerja merupakan salah satu faktor yang penting dalam menjamin kerhasilan strategis organisasi.

Kinerja dapat diartikan sebagai penilaian bagaimana hasil ekonomi dari kegiatan industry memberikan kontribusi terbaik guna mencapai tujuan. Dari definisi tersebut dapat diartikan bahwa kinerja adalah seberapa baik hasil yang dicapai oleh perusahaan dalam mencapai tujuan perekonomian, dimana tujuan perekonomian adalah untuk memaksimalkan kesejahtraan ekonomi (Sukarno dan Syaichu, 2006).Kinerja bank pada umumnya diukur dengan menggunakan indkator tingkat kesehatan bank sebagai ukuran kinerja (Putri dan Lukviarman, 2008). 


\section{METODE PENELITIAN}

Penelitian ini adalah penelitian kuantitatif. Dengan menggunakan pendekatan komperatif. Pendekatakan komperatif adalah penelitian yang membandingkan keadaan satu variabel atau lebih pada dua atau lebih sampel yang berbeda, atau dua waktu yang berbeda (Sugiyono, 2014) Data dalam penelitian ini bersumber dari data sekunder. Data sekunder merupakan data-data yang telah tersedia yang berasal dari laporan keuangan yang terdaftar dan di publikasikan di Bank Indonesia. Populasi dalam penelitian ini adalah Bank Mega Syariah dan Bank CIMB Niaga Syariah Periode 2010-2016. Teknik analisis yang digunakan dalam penelitian ini yaitu Data Envelopment Analysis (DEA) dengan pendekatan rasio untuk mengukur tingkat efisiensi penyaluran kredit dan Uji beda Independent T-sample.

\section{HASIL DAN PEMBAHASAN}

\section{Efisiensi Penyaluran Kredit dengan Data Envelopment Analisis (DEA).}

Efisiensi adalah salah satu parameter kinerja yang secara teoritis untuk mengukur kinerja yang mendasari seluruh kinerja organisasi. Efesiensi dalam dunia perbankan lazim digunakan untuk memberikan jawaban atas berbagai kesulitan dalam menghitung berbagai ukuran kinerja. Perhitungan efisiensi Bank menggunakan metode Data Envelopmet Analysis (DEA) menggunakan tiga variabel input meliputi total simpanan, total aset, dan biaya tenaga kerja. Sedangkan outputnya yaitu total kredit atau pembiayaan dan laba operasional.

Berikut ini adalah total efisiensi penyaluran kredit pada Bank Mega Syariah dan Bank CIMB Niaga Syariah adalah sebagai berikut :

Tabel 1. Total tingkat efisensi penyaluran kredit Bank Mega Syariah dan Bank CIMB Niaga Syariah Tahun 2010-2016

\begin{tabular}{ccc}
\hline Tahun & $\begin{array}{c}\text { Efisiensi Penyaluran } \\
\text { Kredit Bank Mega } \\
\text { Syariah }\end{array}$ & $\begin{array}{c}\text { Efisiensi Penyaluran Kredit } \\
\text { Bank CIMB Niaga Syariah }\end{array}$ \\
\hline 2010 & $19 \%$ & $41 \%$ \\
2011 & $10 \%$ & $44 \%$ \\
2012 & $9 \%$ & $31 \%$ \\
2013 & $7 \%$ & $23 \%$ \\
2014 & $3 \%$ & $24 \%$ \\
2015 & $4 \%$ & $17 \%$ \\
2016 & $22 \%$ & $49 \%$ \\
\hline Rata-rata & $30 \%$ & $70 \%$ \\
\hline
\end{tabular}

Sumber : Data diolah manual dengan menggunakan pendekatan rasio efisensi Data Envelopment Analysis (DEA).

Pada Tabel 4.6 menunjukan total efisiensi penyaluran kredit pada Bank Mega Syariah dan Bank CIMB Niaga Syariah tahun 2010-2016 yang menunjukan bahwa total efiseinsi penyaluran kredit Bank Mega Syariah mengalami fluktuasi dan bisa dilihat pada tahun 20102015 mengalami penurunan dari 19\% menjadi 4\%, sementara itu pada tahun 2016 meningkat lagi dengan angka $22 \%$, dengan total rata-rata efisiensi penyaluran kredit $30 \%$, ini berarti Bank Mega Syariah belum efisien. Sementara itu pada Bank CIMB Niaga Syariah mengalami peningkatan dari tahun 2010-2016 dari total efisiensi penyaluran kredit 41\% menjadi 49\%, sehingga dapat dirata-ratakan total efisiensi $70 \%$ ini menunjukan bahwa Bank CIMB Niaga Syariah mencapai 100\% dan layak dikatakan bahwa Bank tersebut efisien. 


\section{Gambar 1. \\ Presentase tingkat efiseinsi penyaluran kredit Bank Mega Syariah dan Bank CIMB Niaga Syariah Tahun 2010-2016}

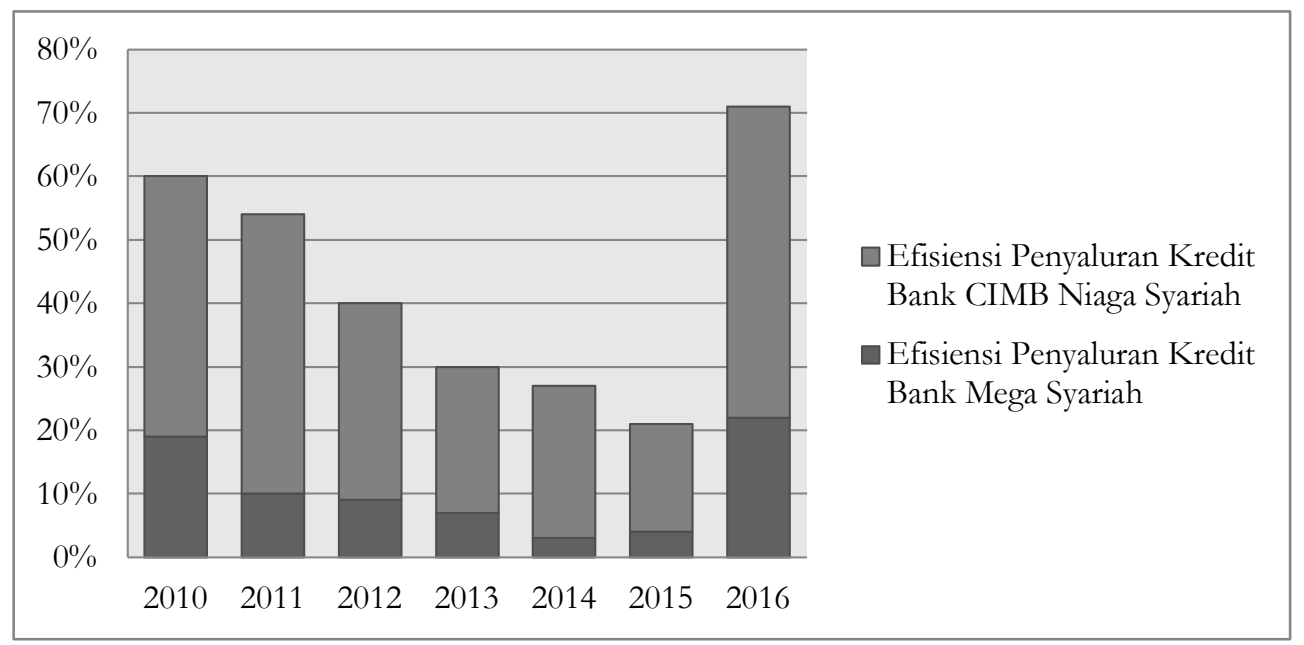

Pada Gambar 4.6 presentasi perkembangan total efisiensi penyaluran kredit menunjukan bahwa tingkat efisiensi penyaluran kredit pada Bank CIMB Niaga Syariah lebih dapat dikatakan efisien dibandingkan dengan Bank Mega Syariah yang hanya mencapai 30\%. Bank yang belum memaksimalkan input dan output yang dimilikinya dapat dikatakan sebagai bank yang inefisien. Hal tersebut berarti nilai input dan outpunya yang dicapai oleh bank yang infisien belum dapat meraih target yang sebenarnya. Berdasarkan hasil penelitian tetantang tingkat efisiens bank terdapat Bank Mega Syariah yang mengalami Infisiens. Sementara itu yang mencapai tingkat efisiensi adalah Bank CIMB Niaga Syariah dengan total efisiensi penyaluran kredit $70 \%$.

\section{Perbandingan tingkat efisiensi antara Bank Mega Syariah dan Bankj CIMB Niaga Syariah Periode 2010-2016.}

Untuk mengetahui perbandingan efiseinsi antara Bank Mega Syariah dan Bank CIMB Niaga Syariah dalam penelitian dilakukan dengan menggunakan uji beda independent t-test. Digunakan untuk menguji signifikan beda rata-rata antara Bank Mega Syariah dan Bank CIMB Niaga Syariah. Tujuan dari uji hipotesis yang berupa uji beda independent t-test pada penelitian ini adalah untuk menetrasi kebenaran atau kesalahan hipotesis, atau dengan kata lain untuk menerima atau menolak hipotesis yang dibuat. Jika $\mathrm{F}$ hitung dengan Equal variance assumed (diasumsi kedua varians sama) memiliki nilai sig $>0.05$ maka dinyatakan diterimah begitupun sebaliknya. Untuk menentukan uji hipotesis dengan menggunakan uji beda independent t-test diperoleh hasil berikut :

Tabel 2. Perbandingan efisiensi penyaluran kredit Bank Mega Syariah dan Bank CIMB Niaga Syariah Tahun 2010-2016

\begin{tabular}{lllccc}
\hline & Efisiensi & $\mathbf{N}$ & Mean & Std. Deviation & Std. Error Mean \\
\hline Efisiensi & Mega Syariah & 28 & .0250 & .01696 & .00321 \\
& CIMB & 28 & .0810 & .04500 & .00850 \\
\hline
\end{tabular}

Sumber: Olah data sekunder menggunakan SPSS

Berdasarkan hasil uji dari Tabel 4.8 diatas menunujukan nilai mean pada Bank Mega Syariah sebesar 0250 dan pada Bank CIMB Niaga Syariah mempunyai mean sebesar 0810 artinya bahwa dapat dilihat terdapat perbandingan tingkat efisiensi penyaluran kredit antara 
Bank Mega Syariah dan Bank CIMB Niaga Syariah sesuai dengan hipotesis pada penilitian ini yakni, terdapat perbedaan signifikan efesiensi penyakuran kredit Bank Mega Syariah dan Bank CIMB Niaga Syariah selama periode 2010-2016. Sehingga dapat disimpulkan bahwa nilai efisiensi yang lebih tinggi adalah Bank CIMB Niaga Syariah dibandingkan dengan Bank Mega Syariah. Hal ini membuktikan bahwa tingkat efisiensi penyaluran kredit mempengaruhi kinerja bank, semakin efisien bank tersebut maka semakin bagus kinerjanya. Maka dari itu untuk mencapai tahap efisien pihak bank perlu mengadakan perbaikan terutama dari segi input dan outputnya.

\section{Uji Beda Indenpent Sample T-test}

Tabel 3. Hasil uji beda Independent Sample T-test

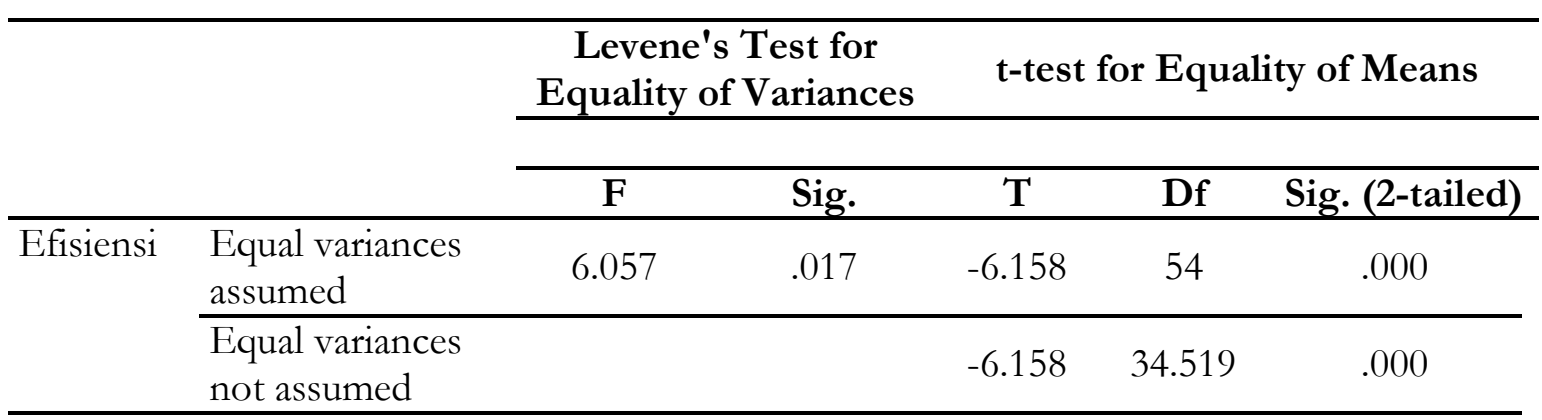

Sumber: Olah data sekunder menggunakan SPSS

Berdasarkan hasil uji hipotesis menunjukan nilai sig .017 lebih besar daripada 0,05 Ho : diterima. Dapat diartikan bahwa terdapat perbedaan yang berarti efisien antara Bank Mega Syariah dan Bank CIMB Niaga Syariah. Dari hasil pengujian besar t hitung yang diperoleh adalah -6,158 maka dapat disimpulkan bahwa t hitung $<$ t tabel sehingga Ho diterima. Karena probabilitasnya $\alpha>=0,05$ maka Ho diterima. Nilai signifikan dari output SPSS ialah sebesar 0,000 dan lebih kecil dari 5\% maka hipotesis diterima.

Berdasarkan hasil penelitian ini menjelaskan bahwa jumlah input dan output baik untuk Bank Mega Syariah maupun Bank CIMB Niaga Syariah mengalami rata-rata efisiensi yang berfluktuasi selama periode 2010-2016. Namun dalam penelitian ini Bank Mega Syariah mengalami inefisiensi. Inefisiensi terjadi pada variable input berupa total simpanan, total aset, dan biaya tenaga kerja, sedangkan pada variable outputnya yaitu total kredit atau pembiayaan dan laba operasional. Sutawijaya dan lestari (2009) menyatakan bahwa pengukuran efisiensi teknik cenderung terbatas hanya pada hubungan teknik dan operasional dalam proses konversi input menjadi output. Hal tersebut bearti bahwa untuk meningkatkan efisiensi teknik hanya perlu menggunakan kebijakan mikro yang bersifat internal, yaitu dengan cara pengendalian dan mengalokasikan sumber daya secara optimal.

1. Ketidakefisienan penggunaan input simpanan oleh Bank Mega Syariah dan Bank CIMB Niaga Syariah terlihat dengan jumlah input total simpanan yang masih lebih besar dibandingkan tergetnya. Hal ini menandakan bahwa perannya sebagai input tidak maksimal untuk menghasilkan output. Upaya yang bisa dilakukan adalah dengan mengalokasikan input simpanan yang berlebih ke bagain total aset khusunya aset yang bersifat produktif dan kredit perdagangan untuk bank konvensional, serta pembiayaan mudharabah, istishna, dan ijarah. Salah satu cara lainya adalah dengan menaikan biaya administrasi pada dana simpanan seperti tabungan, sehingga pendapatan bank dapat lebih baik lagi. Kenaikan biaya adminitrasi juga harus diikuti dengan peningkatan kualitas pelayanan bank agar bank tersebut tetap dapat mampu bersaing. 
Murtiadi Awaluddin, et al. Komparasi Efisiensi Penyaluran Kredit...

2. Ketidakefisiensienan input aset terjadi karena penggunaan jumlah aset melebihi target yang dibutuhkan. Aset adalah seluruh kekayaan yang dmiliki oleh bank meliputi kas, giro pada Bank Indonesia, penempatan pada bank lain, surat berharga yang dimiliki. Solusi yang dapat dilakukan adalag dengan menambahkan porsi pembiayaan yang merupakan bagian dari aset total itu sendiri. Meningkatnya jumlah pembiayaan akan memperlancar proses intermediasi baik Bank Mega Syariah maupun Bank CIMB Niaga Syariah dan menambah pendapatan opeasional terutama yang berasal dari penyaluran dana. Sedangkan aset tetap yamg telah dimiliki oleh bank tidak perlu dikurangi, hanya saja digunakan secara maksimal agar tidak terjadi inefisiensi. Pembelian aset yang harus sejalan dengan penggunaanya secara maksimal sehingga berpengaruh positif terhadap pendapatan bank.

3. Inefisiensi input biaya tenaga kerja terjadi karena jumlah biaya tenaga kerja yang harus dikeluarkan lebih besar dari yang dibutuhkan. Besarnya biaya tenaga kerja bisa diakibatkan karena banyaknya jumlah tenaga kerja yang digunakan. Bank Mega Syariah dan Bank CIMB Niaga Syariah memiliki masalah yang sama, yaitu peningkatan jumlah tenaga kerja tidak diimbangi dengan skill yang memadai sehingga menyebabkan bank mengalami penuruanan produktivitas (Sutawijaya dan Lestari, 2009).

Dengan hasil ini, sehingga hipotesis yang menyatakan dalam penilitian ini terdapat perbedaan signifikan efesiensi penyakuran kredit Bank Mega Syariah dan Bank CIMB Niaga Syariah selama periode 2010-2016 diterimah. Hal ini selaras dengan penelitian yang dilakukan Tessa Magrianti (2011) yang berjudul "Analisis Perbandingan Efisiensi Bank Umum Syariah dengan Bank Bank Umum Konvensional di Indonesia dengan menggunakan Data Enevelopment Analysis (DEA) periode 2004-2009" yang menyatakan bahwa terdapat perbedaan efisiensi penyaluran kredit Bank Umum Syariah dan Bank Umum Konvensional di Indonesia. Sehingga dapat disimpulkan bahwa nilai efisiensi yang lebih tinggi adalah Bank CIMB Niaga Syariah dibandingkan dengan Bank Mega Syariah. Ini membuktikan bahwa tingkat efisiensi penyaluran kredit mempengaruhi kinerja bank. Semakin efisien bank tersebut maka semakin bagus kinerjanya. Semantara itu hasil penelitian menunjukan bahwa Bank Mega Syariah dinyatakan infesiensi karena tingkat efisiensi penyaluran kredit belum mencapai angka yang maksimal, dan pada Bank CIMB Niaga Syariah dinyatakan efisiensi karena sudah mencapai angka makasimal untuk ukuran sebuah tingkat efisiensi. Jika dlihat dari hasil penelitian bahwa tingkat efisiensi penyaluran kredit Bank CIMB Niaga Syariah lebih baik dibandingkan dengan Bank Mega Syariah.

\section{PENUTUP}

Berdasarkan hasil dari data dan pembahasan yang telah diarahakan pada bab sebelumnya mengenai Perbandingan Efisiensi Penyaluran Kredit Bank Umum Syariah antara Bank Mega Syariah dan Bank CIMB Niaga Syariah dengan menggunakan Data Envelopment Analysis (DEA), maka dapat disimpulkan sebagai berikut :

1. Hasil perhitungan tingkat efisiensi penyaluran kredit pada Bank Mega Syariah mengalamai fluktuasi selama 2010-2016 dengan rata-rata efisiensi yang paling tinggi pada tahun 2016 dan paling rendah pada tahun 2014 dari tingkat efisiensi penyaluran kredit Hal ini membuktikan bahwa Bank Mega Syariah belum dapat dikatakan efisien.

2. Hasil perhitungan tingkat efisiensi penyaluran kredit pada Bank CIMB Niaga Syariah mengalamai fluktuasi selama 2010-2016 dengan rata-rata efisiensi yang paling tinggi pada tahun 2016 dan paling rendah pada tahun 2013 Dari tingkat efisiensi penyaluran kredit. Hal ini mebuktikan bahwa Bank CIMB Niaga Syariah bisa dikatakan efisien

3. Terdapat perbedaan secara signifikan tingkat efisiensi penyaluran kredit Bank Mega Syariah dengan Bank CIMB Niaga Syariah. Dimana dalam penelitian ini Bank CIMB 
AL-MASHRAFIYAH: Jurnal Ekonomi, Keuangan, dan Perbankan Syariah Volume 3, Nomor 2, Oktober 2019

Niaga Syariah lebih baik di bandingkan dengan Bank Mega syariah. Hal ini mengindikasikan bahwa Bank CIMB Niaga Syariah telah menjalankan fungsi intermediasinya dengan baik meskipun belum berada pada tingkat efisiensi $100 \%$.

\section{DAFTAR PUSTAKA}

Abiding, Zainal dan Endri, Kinerja Efisiensi Teknik Bank Pembangunan Daerah, pendekatan Data Envelopment Analysis (DEA). Jurnal Akuntansi dan Keuangan, 2009,Vol.II. No1.

Adrian Sutawijaya, dan Etty Puji Lestari, Efesiensi Teknik Perbankan Indonesia Pascakrisis Ekonomi, Sebuah Studi Empiris Penerapan Model DEA, Jurnal Ekonomi Pembangunan, 2009, Vol.10. No.1, h. 52.

Afif Amirillah, Efesiensi Perbankan Syariah Di Indoensia, Journal Of Economic and Policy, 2014, No.2, h.146.

Aji Firman, dan Gunawan, Analisis Tingkat Efisiensi Bank BUMN Dengan Pendekatan Data Envelopment Analysis (DEA), Jurnal Ekonomi Keuangan,2013, No.1,h.12.

Antonio, Muhammad Syafi'i.Bank Syariah Dari Teori ke Praktik. Jakarta:Gema Insani Press.2007.

Ascarya, Guruh. Efesiensi Bank Umum Konvensional dan Bank Umum Syariah, Jurnal Ekonomi dan Bisnis, 2008, Vol.3. No.1, h.13.

Arnold Reisman, dkk, The Effect Of Scale and Mode of Ownership On The Financial Performance Of The Turkish Banking Sector Result Of a DEA Based Analysis, Socio Economic Planning Sciences, 2003, Vol.37. h.185-202.

A'yuni Qurrota, Analisis Efisiensi Kinerja Keuangan KPRI di Kota Malang Dengan Metode Data Envelopment Analysis (DEA), Journal Of Economic and Policy, 2014, No.2, h.146.

Awaluddin, M., \& Nirgahayu, R. S. W. The Effect Of Expert Management, Professional Skepticism And Professional Ethics On Auditors Detecting Ability With Emotional Intelligence As Modeling Variables.

Bachruddin. Pengaruh Sektor Perbankan terhadap perekonomian Indonesia. Jurnal Ilmu Manajemen dan Perbankan, 2000, Vol.1. No.3, h.5.

Bhava Wahyu, Analisis Efisiensi Perbankan Menggunakan Metode No Parametri Data Envelopment Analysis, Jurnal Ekonomi dan Bisnis, 2013, Vol.3. No.1, h.13.

Bank Indonesia. 2018. Laporan Keuangan Bank CIMB Niaga Syariah. http://www.bi.go.id. Diakases tanggal 28 Juli 2018.

Bank Indonesia. 2018. Laporan Keuangan Bank Mega Syariah. http://www.bi.go.id. Diakases tanggal 28 Juli 2018.

Booklet Perbankan Indonesia. Booklet Perbankan Indoensia Edisi 3 Maret 2016. Jakarta.2016.

Coelli T.J, A Guide to DEAP Version 2.1 : A Data Envelopment Analysis (Computer) Program, No 8/96. Center For Efficiency and Productivity Analysis Departement of Econometric Unversity of New England Armidale, NSW,2351. Australia. 1996. 
Murtiadi Awaluddin, et al. Komparasi Efisiensi Penyaluran Kredit...

Departemen Agama RI, Al-Quran danterjemahannya, (Bandung: Ju,amatul Ali-Art, 2002).

Dias Satria dan Rangga Bagus Subegti, Detreminasi Penyaluran Kredit Bank Umum Di Indonesia Periode 2006-2009, Jurnal Keuangan dan Perbankan, 2007, Vol.14. No.3, h.417.

Fauzi, Muhammad. Metode Penelitian Kuantitaif Suatu Pengantar. Semarang: Walisongo Press.2009.

Gunawan, Firman Aji, Analisis Tingkat Efesiensi Bank BUMN Dengan Pendekatan Data Envwlopmwnt Analysis (DEA), Jurnal Ilmu dan Riset manajemen, 2013, Vol.2. No.1, h.5.

Hadad. Envelopment Analysis. Jakarta:PT.Raja Grafindo.2003.

Harjum Muharram, dan Rizki Pusvitasari, Analisis Perbandingan Efesiensi bank Syariah Di Indonesia Dengan Metode Data Envelopment Analysis (Periode tahun 2005), Fakultas Ekonomi Universitas Diponegoro Semarang, 2007, Vol.2. No.3, h.85.

Hendi Septianto dan Tatik Widiharih, Analisis Efesiensi Bank Perkredta Rakyat Di Kota Semarang Dengan Pendekatan Data Envelopment Analysis, Jurnal Media Statistik, 2010, Vol.3. No.1, h.42.

Heri Pratikto, dan Iis Sugianto, Kinerja Efesiensi bank Syariah Sebelum dan Sesudah Krisis Global Berdasarkan Data Envelopment Analysis, Jurnal Ekonomi Bisnis, 2011, Vol.16. No.2, h.112.

Huri, Susilowati. Perbandingan Efesiensi Bank Umum Konvensional dan Bank Umum Syariah, Jurnal Ekonomi dan Bisnis, 2004,Vol.1. No.2,,h.7.

Imam Subaweh, Analisis Perbandingan Kinerja Keuagan Bank Syariah dan Bank Konvensional Periode 2003-2007, Jurnal Ekonomi Bisnis, 2008, Vol.13. No.2, h.116.

Kasmir.Manajemen Perbankan. Jakarta: PT.Raja Grafindo Persada.2012.

Kasmir. Bank dan Lembaga Kenangan Lainnya. Edisi Revisi 2014. Jakarta: PT. Raja Grafindo Persada. 2014.

Kasmir. Bank dan Lembaga Kenangan Lainnya. Edisi Revisi 2015. Jakarta: PT. Raja Grafindo Persada. 2015.

Karim.Perbankan. Jakarta: PT.Raja Grafindo Persada.2004.

Karim.Bank Islam. Jakarta: PT.Raja Grafindo Persada.2014.

Kurnia. Analisis Perbandingan bank Umum Konvensional dan Bank Umum Syariah di Indonesia Dengan Metode data Envelopment Analysis (DEA).Jurnal Ilmu Manajemen dan Perbankan, 2004, Vol.2. No.1, h.12.

Magrianti, Tessa. Analisis Perbandingan Efisiensi Bank Umum Syariah dengan Bank Umum Konvensional di Indonesia. Jurnal Manajemen dan Bisnis, 2011.

Meoli Michele, dkk, Efficiensy Of Microfinance Institutions In Sri Lanka, a Two Stage Double Bootstrap DEA Approach, Journal Home Page : wnw.elsavier.com/locate/ecmod, 2015, h.7483.,

Muharam, Pusvitasari. Penilaian Efesiensi Bank Umum Konvensional dan bank Umum Syariah, Jurnal Ekonomi dan Perbankan, 2007, Vol.3,h.16. 
AL-MASHRAFIYAH: Jurnal Ekonomi, Keuangan, dan Perbankan Syariah Volume 3, Nomor 2, Oktober 2019

Mulyadi.Akuntasi Biaya Edisi 5, Yogyakarta:Aditya Media.2000.

Mumu Daman Huri dan Indah Susilowati, Pengukuran Efesiensi Relatif Emiten Perbankan Dengan Metode Data Envelopment Analysis (DEA), Dinamika Pembagunan, 2004, Vol.1. No.2, h.97.

Rafika Rahmawati, Strategi Peningkatan Efesiensi Biaya Pada bank Umum Syariah Berbasis Stochastic Frontier Approach dan Data Envelopment Analysis, Buletin Ekonomi Moneter dan Perbankan, 2015, Vol.17. No.4, h.462.

Razono Agall Cahyadi, dkk, Perbedaan Efesiensi bank Umum Konvensional, Pendekatan data Envelopment Analysis, Jurnal Ekobisman, 2018, Vol.2. No.3, h.243.

Santoso, Singgih. Seri Solusi Bisnis Berbasis TI Menggunakan SPSS untuk Statistik Parametrik. Jakarta: Elex Media Komputindo. 2005.

Setiawan, Arif. Perbandingan antara Bank Umum Konvensional dan Bank Umum Syariah, Jurnal Ilmu Manajemen dan Perbankan, 2013, Vol.3. No.1, h.12.

Sudarsono. Manajemen Perbankan. Jakarta: PT.Gramedia Pustaka Utama.2008.

Sugiyono. Metode Penelitian Manajemen. Bandung: Alfabeta.2015.

Sugiyono. Metode Penelitian Manajemen. Bandung: Alfabeta.2013.

Sutawijaya, Lestari. Analisis Efesiensi Bank Umum Konvensional dan Bank Umum Syariah dengan Menggunakan Metode Envelopment Analysis (DEA), Jurnal Ekonomi dan Perbankan, 2009, Vol.22, h.12-15.

Uctavia, Uma. Bank Umum Konvensional dan Bank Umum Syariah, Jurnal Ekono I dan Bisnis, 2013, Vol.3, No.1, h.12.

Purwanto, Rahmat. Analisis Perbandingan Efisiensi Bank Umum Konvensional (BUK) dan Bank Umum Syariah (BUS) di Indonesia dengan Metode Data Envelopment Analysis (DEA) Periode 2006-2010. Jurnal Skripsi Fakultas Ekonomi Unversitas Diponegoro.2011,Hal $1-30$.

P.Zhou, dkk, A Survey of Data Envelopment Analysis In Energy and Environmental Studies, European Journal Of Operational Research, 2008, h.1-18.

Wahyu Nugraha, Analisis Efesiensi Perbankan Menggunkan Metode Non Parametri Data Envelopment Analysis (DEA), Jurnal Ilmu Manajemen, 2013, Vol.1. No.1, h.276.

Wardhani, R. S., Marwa, T., Fuadah, L., Siddik, S., Awaluddin, M., \& Hadjri, M. I. (2019). GOOD UNIVERSITY GOVERNANCE: BUDGETING PARTICIPATION AND INTERNAL CONTROL. Asia-Pacific Management Accounting Journal, 14(1), 1-17. 